\title{
PELATIHAN PEMBUATAN VIDEO AJAR UNTUK MENINGKATKAN KUALITAS PEMBELAJARAN DARING
}

\author{
Laily Nurlina ${ }^{1}$, Akhmad Fauzan $^{2}$ \\ 1,2Universitas Muhammadiyah Purwokwerto, Jl. Raya KH. Ahmad Dahlan Banyumas, Jawa Tengah \\ Email: lailynurlina@ump.ac.id
}

\begin{abstract}
This community service activity aims to train teachers of SMP Muhammadiyah 2 KarangLewas Purwokerto, Central Java to develop teaching media (videos) so that they can maximize online learning. Application for editing videos using Kinemaster with a laptop or mobile phone. The choice of Kinemaster because it is light and does not burden the cellphone or laptop, easy to install and easy to use online. The methods used are (1) introduction to Kinemaster, (2) how to download the Kinemaster application, and (3) simulation of using the Kinemaster application to edit videos. The material begins with an explanation of the differences between the Distance Learning RPP and the Covid 19 Emergency Curriculum RPP or one sheet RPP. As many as 15 teachers who participated in this activity were able to make audio-visual (video) teaching media and practice it in front of their friends. They said that this training was able to add insight, know the right lesson plans for PJJ and be able to make teaching media more attractive.
\end{abstract}

Keywords: Training; Video Application; Kinemaster, Editing; Online Learning.

\begin{abstract}
ABSTRAK
Kegiatan pengabdian kepada masyarakat ini bertujuan untuk melatih guru-guru SMP Muhammadiyah 2 KarangLewas Purwokerto Jawa Tengah untuk mengembangkan media ajar (video) sehingga dapat memaksimalkan pembelajaran daring. Aplikasi untuk menyunting video menggunakan Kinemaster dengan laptop atau telepon genggam. Pemilihan Kinemaster karena ringan dan tidak membebani Hp atau laptop, mudah diinstal dan mudah digunakan secara online. Metode yang digunakan adalah (1) Pengenalan Kinemaster, (2) Cara mengunduh aplikasi Kinemaster, dan (3) Simulasi penggunaan aplikasi Kinemaster untuk mengedit video. Materi diawali dengan penjelasan perbedaan antara RPP Pembelajaran Jarak Jauh dan RPP KurikulumDarurat Covid 19 atau RPP satu lembar. Sebanyak 15 guru yang mengikuti kegiatan ini telah mampu membuat media ajar audio visual (video) dan mempraktikan di depan temantemannya. Mereka mengatakan bahwa pelatihan ini mampu menambah wawasan, mengetahui RPP yang tepat untuk PJJ dan mampu membuat media ajar yang lebih menarik.
\end{abstract}

KataKunci: Pelatihan; Aplikasi Video; Kinemaster; Menyunting; Pembelajaran Daring.

\section{PENDAHULUAN}

Pembelajaran daring di sekolah mengacu pada surat edaran Kemendikbud Nomor 40 Tahun 2020 tentang Pelaksanaan Kebijakan Pendidikan dalam Masa Darurat Penyebaran Corona Virus Disease (COVID 19). Menteri Pendidikan dan Kebudayaan (Mendikbud), Nadiem Makarim, menyampaikan beberapa kebijakan dalam menghadapi pandemic terkait erat dengan penetapan belajar dari rumah (pembelajaran daring). Awalnya, kebijakan pembelajar daring disetujui dan dianggap paling tepat karena dapat mencegah peserta didik yang rentan 
terkena virus. Hampir satu tahun pembelajar daring dilaksanakan dan mulai bermunculan masalah-masalah yang menitikberatkan pada kemampuan guru mengajar dan kemampuan peserta didik untuk memahami materi yang diajarkan. Kegelisahan muncul karena banyak orang tua yang kewalahan dalam mendampingi putra-putrinya belajar. Data ini didapatkan melalui wawancara daring kepada para guru. Siswa SMP masih perlu dibimbing intensif oleh guru sehingga pemahaman materi dapat maksimal. Pembelajaran sering tidak efektif karena peserta didik menganggap rumah bukanlah sekolah sehingga mereka tidak serius ketika belajar dan cenderung bermain sepanjang waktu. Tidak semua orang tua mampu mendampingi putraputrinya belajar dan mereka juga kesulitan dengan teknologi dalam pembelajaran daring.

Kegelisahan juga munculdari para pengajar yang merasa proses pembelajaran kurang efektif dan mencapai indikator yang ditetapkan. Guru matematika, guru ilmu pengetahuan alam, dan guru olahraga merasa kurang dalam menyampaikan materi karena tidak memantau langsung pemahaman peserta didik. Mereka merasa kurang ilmu dan pengalaman untuk melaksanakan pembelajaran daring karena kemampuan mengembangkan media ajar masih kurang menarik dan kurang inovatif.

Nurlina (2021: 102) menemukan bahwa di tingkat mahasiswa perlu dibuat perencanaan pembelajaran yang sesuai dengan kebutuhan mereka. Pembelajaran daring dapat meningkatkan motivasi belajar dan Problem Based Learning (Pembelajaran Berbasis Masalah) dapat meningkatkan kemampuan mahasiswa dan kerjasama di antara mahasiswa. Berdasarkan pengamatan, semua guru mempunyai minimal satu telepon genggam android yang dapat dimaksimalkan untuk mengembangkan media ajar daring. Salah satua plikasi penyuntingan video yang sesuai dengan telepon genggam android adalah Kinemaster. Aplikasi ini banyak digunakan karena praktis dan mempunyai banyakfitur yang mudah diaplikasikan. Beberapa fitur yang ada dalam Kinemaster antara lain memangkas video yang tidak dibutuhkan, menambah audio, menambah teks, membuat transisi menjadil ebih halus dan menyensor bagian video yang dianggap kurang sesuai. Seluruh proses ini dapat dilakukan dengan cepat dan praktis.

Salahudin (2020: 132) menggunakan Kinemaster untuk meningkatkan kemampuan kosakata bahasa Arab pada Siswa kelas VIII MTs Nurul Huda, Tuban. Media video animasi yang dibuat oleh peneliti ini mampu memotivasi siswa untuk lebih senang belajar bahasa Arab dan meningkatkan kemampuan berbahasa Arab mereka apabila dilihat dari segi kognitifnya. Dewi (2020 :71) mengembangkan video animasi berbantuan Kinemaster untuk pembelajaran sulam pada siswa kelas XI SMKN 1 Depok. Hasil Riset and pengembangannya (R\&D) mampu diterima dan layak digunakan untuk mengajar Tata Busana berdasarkan uji terbatas dan uji luas yang dilaksanaka oleh peneliti. 
Kelebihan Kinemaster yaitu 1) integrasi di sosial media sehingga video ajar guru dapat menjangkau audiens lebih luas dan lebih tepat sasaran, 2) fitur-fitur yang super porwerful dan mudah digunakan oleh orang awam sekalipun, 3) efek transisi terlihat professional dan tidak berlebihan, 4) user interface yang simple sehingga memudahkan dalam menyunting, 5) layer multi untuk dapat menambahkan lebih dari satu layer baikgambar, teks, audio maupun video, 6) memiliki filter warna dan fitur penyesuaian warna seperti brightening, mode gelap, dan saturasi, 7) volume envelope berguna untuk menambah atau mengurangi suara atau music, menambah dan mengatur kompresor audio, dan 8) fitur kontrol kecepatan dan klip grafis.

Selain kelebihan, Kinemaster mempunyai kelemahan juga antara lain: 1) terdapat watermark apabila aplikasi yang dipilih tidak berbayar, 2) membutuhkan spek device yang mencukupi, dan 3) kualitas video tidak full HD tetapi tetap dapat ditonton. Kekurangan aplikasi ini tidak terlalu memengaruhi kualitas video dan fungsi media ajar sebagai alat untuk membantu pembelajaran. Untuk itulah tim pengabdian masyarakat dari Universitas Muhammadiyah Purwokerto mencoba menjembatani kesulitan guru dengan memberikan pelatihan teori dan praktik pengembangan media ajar khususnya video dengan menggunakan Kinemaster.

\section{METODE}

Pelatihan pengembangan media ajar (video) dengan menggunakan Kinemaster ini dilaksanakan pada hari Rabu, 17 Februari 2021.Peserta merupakan para pengajar sebanyak 14 orang, satu kepala sekolah, dan dua tenaga kependidikan. Model pelatihannya dengan blended learning karena daerah Purwokerto masih kategori merah/hitam pandemi Covid 19. Para peserta berada di sekolah SMP Muhammadiyah 2 Karanglewas Purwokerto belajar media ajar dengan luring dan pengisi memberikan materi dengan daring. Ada asisten yang membantu di sekolah supaya pelatihan dapat berjalan lancar dan tidak ada kendala komunikasi. Untuk memudahkan para peserta pelatihan dalam mengembangkan media ajar maka pengisi menggunakan metode yaitu

1. Materi tentang RPP Pembelajaran Jarak Jauh

Rencana pelaksanaan pembelajaran yang baik sangat menentukan kualitas pembelajaran itu sendiri. Saat ini, guru-guru dituntut untuk mengubah RPP dan menyesuaikan dengan pembelajaran daring supaya lebih efektif dan efisien. Hal yang perlu ditekankan pada pemilihan bahan ajar dan penggunaan media ajar daring. Banyaknya keluhan dari orang tua tentang kualitas pembelajaran saat ini membuat guru harus lebih kreatif dalam merencanakan pembelajarannya.

2. Materi tentang RPP satu lembar (Kurikulum darurat Covid 19) 
Salah satu solusi untuk memudahkan guru dalam menyiapkan pembelajaran adalah diluncurkannya kurikulum darurat covid 19 oleh bapak Nadiem Makarim. Banyak guru yang masih belum memahami seperti apa bentuk kurikulum satu lembar ini. Pada intinya RPP harus memuat hal-hal penting seperti identitas mata pelajaran, waktu, tujuan, dan evaluasi.

3. Pengenalan aplikasi Kinemaster dan mendampingi install aplikasi di telepon genggam para peserta pelatihan.

Kedua metode di atas diberikan oleh Dr Laily Nurlina, M.Pd tetapi untuk penjelasan materi ketiga disampaikan oleh Bella Carmenia, S.T alumni Universitas Muhammadiyah Purwokerto. Mahasiswa pendamping kegiatan di sekolah yaitu Yaumil Munawaroh membantu guru-guru apabila ada yang kesulitan menginstall Kinemaster.

4. Penjelasan penggunaan aplikasi Kinemaster dalam pembuatan video pembelajaran.

Setelah guru berhasil menginstal aplikasi Kinemaster, pemateri dilanjutkan dengan penjelasan penggunaannya. Setiap fungsi yang ada dalam aplikasi dikenalkan satu-satu dan dibuka sehingga guru dapat memahami dengan baik.

5. Simulasi penggunaan Kinemaster dalam menyunting video pembelajaran.

Guru menyiapkan salah satu video pembelajaran yang sudah ada dalam dokumen mereka. Kegiatan berikutnya adalah simulasi penggunaan Kinemaster untuk menyunting video tersebut. Guru mempraktikan menyunting video mereka setahap demi setahap dengan pendampingan melalui zoom dan mahasiswa yang ada di sekolah.

6. Pengisian daftar hadir untuk pengiriman sertifikat pelatihan dan masukan-masukan untuk kebutuhan kegiatan pengabdian di waktu yang akan datang.

Perwakilan guru menampilkan hasil suntingan mereka dan kegiatan terakhir mengisi kehadiran untuk mendapatkan sertifikat dan memberi masukan-masukan yang bermanfaat untuk kegiatan pengabdian berikutnya.

\section{HASIL DAN PEMBAHASAN}

Narasumber mengenalkan tentang Rencana Pelaksanaan Pembelajaran Jarak Jauh supaya guru dapat memahami diperlukan RPP yang sesuai untuk pembelajaran daring. Salah satu komponen inti adalah media ajar yang dapat digunakan dalam pembelajaran jarak jauh (daring) dengan menyesuaikan kemampuan peserta didik dan fasilitas yang mendukung mereka dalam belajar. 


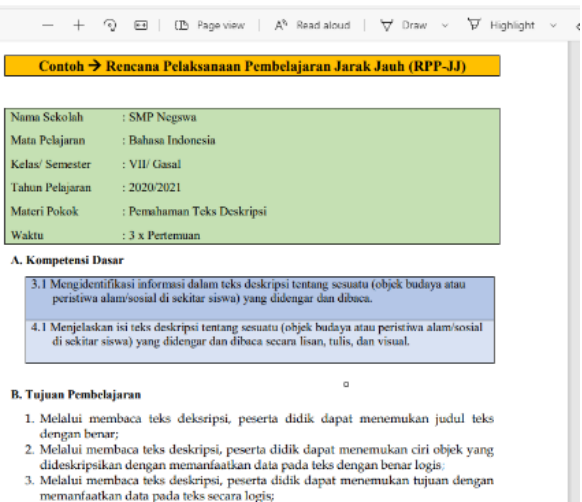

\section{Gambar 1. Rencana Pelaksanaan Pembelajaran (RPP)}

Semua guru telah terbiasa membuat rencana pembelajaran apalagi MGMP (Musyawarah Guru Mata Pelajaran) selalu telah membuat RPP standar untuk mata pelajaran tertentu. Pandemi 19 memaksa para guru untuk beradaptasi dengan perubahan sehingga kegiatan pembelajaran yang biasa dilakukan di kelas menjadi melalui daring. Materi kedua adalah RPP satu lembar yang dilengkapi dengan lembar kerja daring juga sehingga peserta didik mudah dan senang belajar. Dalam lembar kerja, materi dapat menggunakan video ajar sehingga mudah dipahami.

RENCANA PELAKSANAAN PEMBELAJARAN DARING

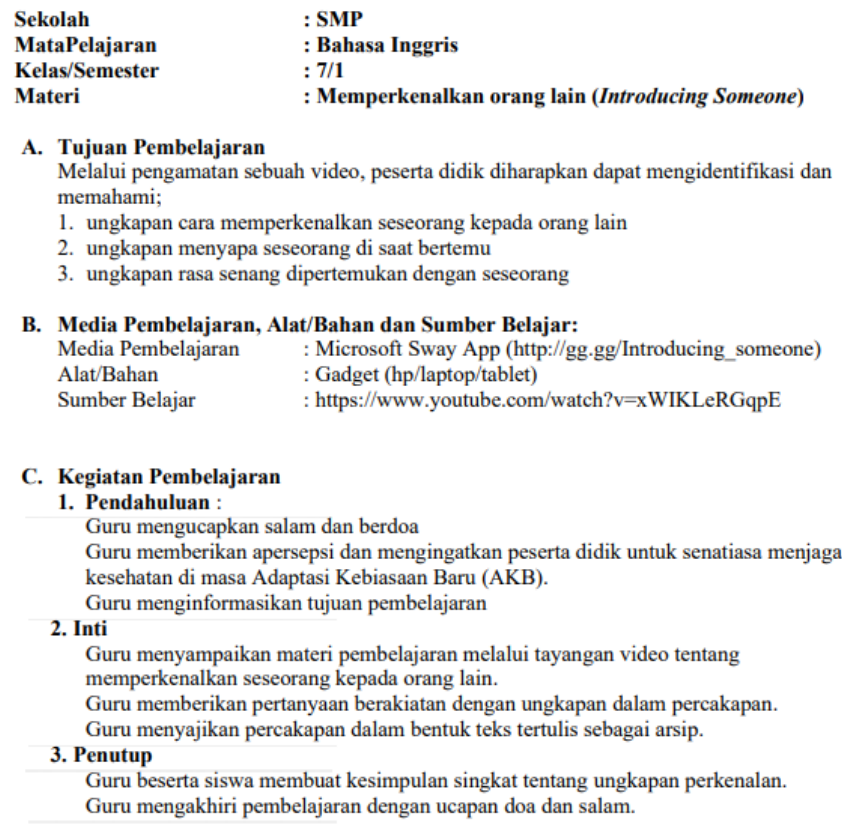

A. Tujuan Pembelajaran

Melalui pengamatan sebuah video, peserta didik diharapkan dapat mengidentifikasi dan memahami;

1. ungkapan cara memperkenalkan seseorang kepada orang lain

2. ungkapan menyapa seseorang di saat bertemu

3. ungkapan rasa senang dipertemukan dengan seseorang

B. Media Pembelajaran, Alat/Bahan dan Sumber Belajar:

Gambar 2. Rencana Pelaksanaan Pembelajaran (RPP) Daring 
Sumber belajar meliputi semua unsur yang dapat digunakan oleh peserta didik baik secara terpisah maupun dalam bentuk gabungan, biasanya dalam situasi informal, untuk memberikan fasilitas belajar. Sumber belajar teridiri dari: orang, isi pesan, bahan dan perangkat lunak, peralatan, metode dan teknik, dan lingkungan. Guru saat ini dituntut menguasai teknologi informasi dan komunikasi. Oleh sebab itu para guru harus dapat mengelola sumber belajar digital dalam pembelajaran. Metode yang digunakan dalam pelatihan pengelolaan sumber belajar digital adalah presentasi,demontrasi, dan praktik. Instrumen yang digunakan dalam pelatihan ini berupa aplikasi pendukung berupa Aplikasi Kinemaster Diamond, Laptop dan gambar-gambar pendukung video. Manfaat dari pelatihan yang telah dilakukan adalah meningkatnya kemampuan guru di SMP 2 Muhammadiyah Karanglewas dalam memanfaatkan, mengelola, dan mengevaluasi sumber belajar digital.

Pendamping pelatihan memantau instalasi aplikasi Kinemaster pada Handphone masing-masing peserta. Setelah peserta berhasil menginstal aplikasi ini, buka aplikasi Kinemaster dan pastikan setiap peserta pelatihan dapat melakukannya.
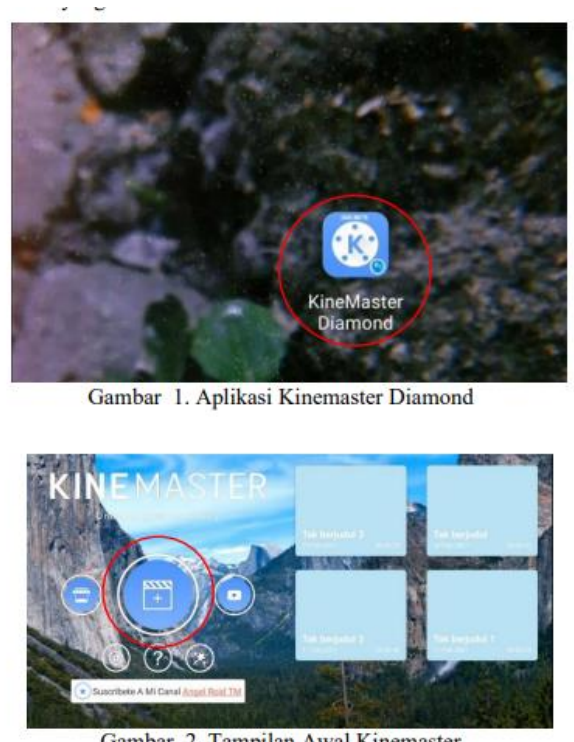

Gambar 2. Tampilan Awal Kinemaster

\section{Gambar 3. Menginstal Aplikasi Kinemaster}

Peserta menyiapkan salah satu video yang dapat digunakan untuk latihan menyunting dengan menggunakan Kinemaster. Pilih icon tambah yang berada di tengah lalu sesuaikan rasio yang akan digunakan dalam video, untuk ukuran rasio video You tube maka gunakan ukuran $16: 9$. 


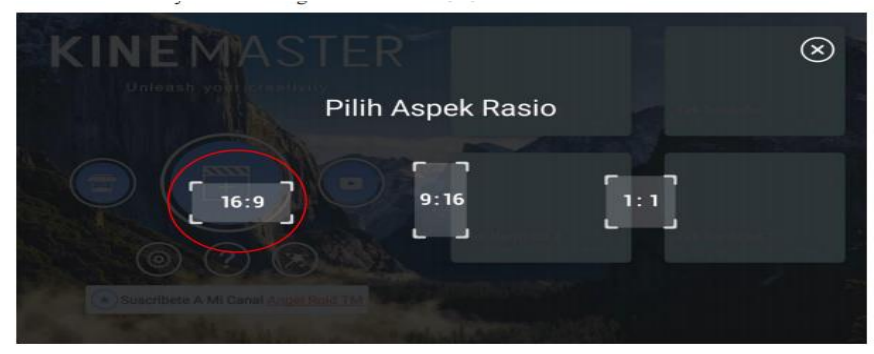

\section{Gambar 4. Cara Menyesuaikan Rasio}

Setelah memilih rasio maka akan tampil halaman untuk mengedit dan menggabungkan video. Untuk memilih latar klik icon media lalu pilih latar.
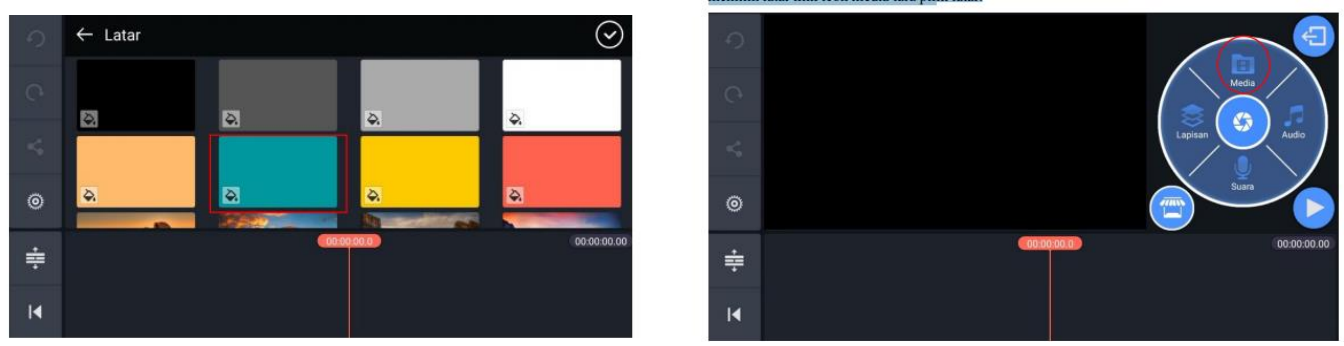

\section{Gambar 5. Cara Memilih Latar}

Pada halaman latar yang yang telah disesuaikan untuk menambahkan gambar klik lapisan, lalu pilih media dan pilih gambar yang akan ditampilkan. Ulangi tahapan 5 setiap kali akan menyisipkan gambar.
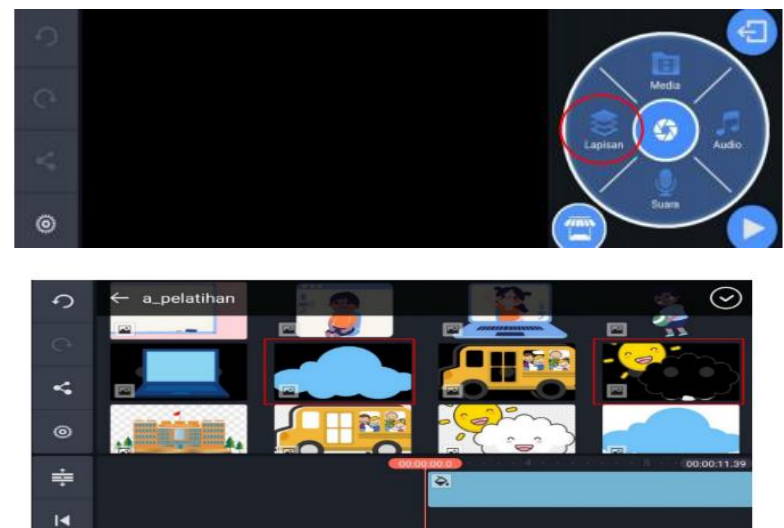

Gambar 6. Cara Menyesuaikan Rasio

Peserta dapat menyisipkan gambar pada video mereka. Tampilan saat gambar berhasil terinput di halaman edit. Setiap elemen yang disisipkan dalam video dapat diatur durasi 
tampilannya dengan cara menarik gambar setiap elemen. Untuk menambahkan latar belakang video dalam format gambar dapat memilih menu lapisan, lalu pilih media kemudian pilih gambar yang akan dijadikan latar belakang video. Setelah menyisipkan latar belakang, pada tahap ini peserta dapat menambahkan keterangan teks. Caranya pilih lapisan lalu pilih bagian teks lalu ketik teks yang akan ditampilkan dalam video.

Pada halaman teks dapat dilakukan modifikasi warna tulisan, font yang akan digunakan, fitur-fitur ini dapat digunakan secara gratis. Untuk mengubah warna klik pada icon warna di samping kanan layer lalu sesuaikan dengan warna yang diinginkan. Tahap selanjutnya adalah menyisipkan atau memasukan element video presentasi yang sebelumnya sudah di rekam secara terpisah. Untuk menambahkan element video dapat pilih lapisan lalu media dan pilih video yang akan dimasukan.

Setelah video berhasil dimasukan, maka kita dapat mengatur atau menghilangkan latar belakang videonya agar terlihat rapih. Penting pada saat akan merekam video presentasi warna background harus berbeda dengan warna pakaian yang kita gunakan, akan lebih baik jika background menggunakan warna hijau.

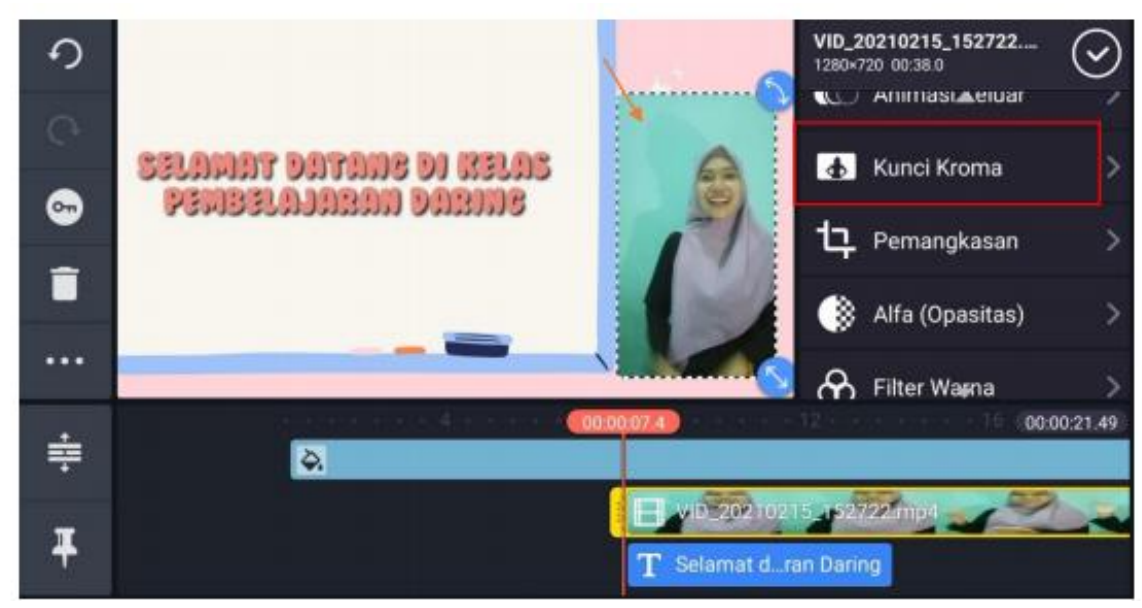

Gambar 7. Mengatur Kunci Krona

Untuk menghilangkan background warna pada video kita dapat memilih menu kunci kroma di samping kanan layer lalu geser tombol agar menjadi aktif. Setelah kunci kroma aktif maka kita dapat mengatur menu yang ditunjukan pada gambar berikut. Kedua menu berikut berfungsi untuk menghilangkan atau menyamarkan background pada video. Tahapan terakhir setelah semua elemen dirasa cukup maka dilakukan proses export atau penyimpanan media agar dapat tersimpan pada perangkat masing-masing peserta. Cara export video pilih tanda cabang pada kiri layar. Suasana pelatihan pengembangan media ajar dapat dilihat pada Gambar 8 berikut 
ini:
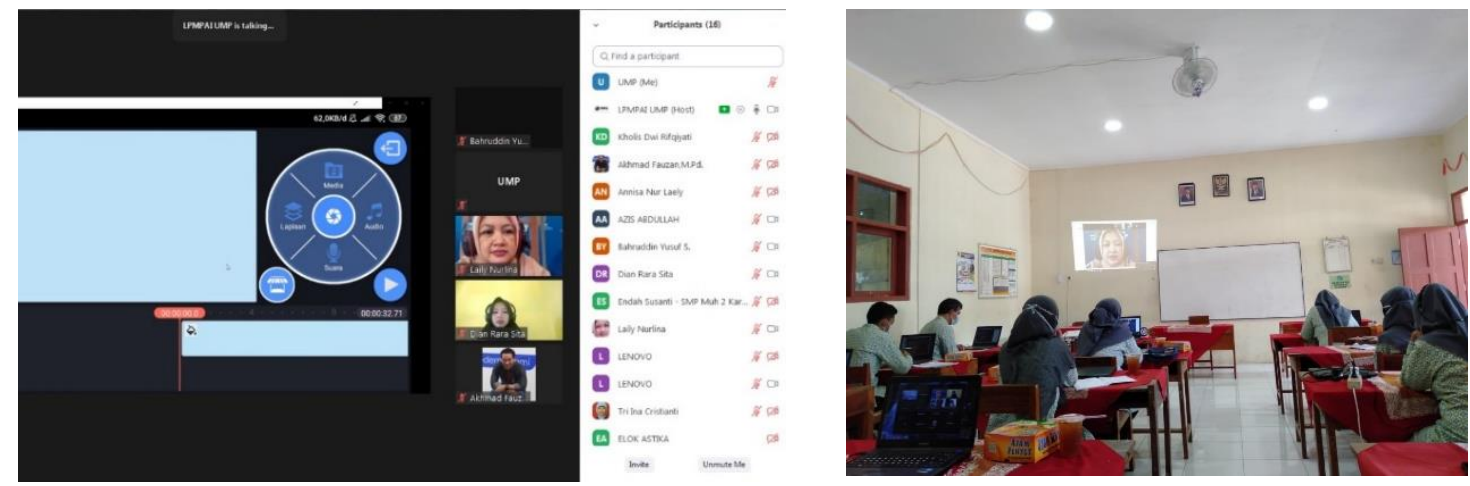

Gambar 8. Suasana Pelatihan

\section{KESIMPULAN}

Hasil akhir pelatihan pengembangan media ajar (video) dengan menggunakan Kinemaster, para guru dapat menyunting dan merancang video yang bagus dan menarik. Kemampuan ini dapat meningkatkan rasa percaya diri guru dalam meningkatkan kualitas pembelajaran mereka.

\section{UCAPAN TERIMA KASIH}

Terimakasih kami ucapkan pada:

1. LPPM Universitas Muhammadiyah Purwokerto yang telah memfasilitasi pengabdian pada masyarakat ini.

2. Kepala Sekolah dan para pengajar SMP Muhammadiyah 2 Karanglewas Purwokerto serta Tenaga kependidikan yang telah berpasrtisipasi aktif dalam kegiatan ini.

3. Tim pengabdian yang sangat kooperatif dan semangat melaksanakan kegiatan pengabdian ini.

\section{REFERENSI}

Depdikbud. 2003. Undang-undang No. 20 Tahun 2003 tentang Sistem Pendidikan Nasional. Semarang: Aneka Ilmu.

Dewi, Agisa PA. 2020. Pengembangan Video Sulaman Smock. Skripsi UNY: tidak dipublikasikan.

Ganesha, Ananda. 2000. Cara Menggunakan Aplikasi KineMaste runtuk Membuat Video. Jakarta Indriani,Eka dan Pangaribuan, TR.2020. Efektifitas Media Kinemaster terhadap Kemampuan Menulis Teks Prosedur Siswa Kelas VII SMP Muhammadiyah 05 Medan. Jurnal Unimed. Vol 9 No. 2. 
Nasution. 2004. Didakti Asas-Asas Mengajar. Jakarta: BumiAksara.

Nurlina,Laily dan Fauzan,Ahmad. 2021.Problem-based Learning Application to Improve Students’ Ability Editing. Syntax Literater: Jurnal Ilmiah Indonesia. Vol 6. No.3.

Republika. Covid-19 dan Potret Pembelajaran Berbasis E-learning. Diakses Rabu,8 April 2020 pukul 14:18 WIB. Penulis Dr. MochamadWahyudiMM.,M.Kom.,M.Pd.

Rusman. 2013. Model-Model Pembelajaran. Jakarta: Rajawali Press.

Salahuddin, Husein.2020. Efektifitas Video Animasi Berbasis Kinemaster untuk Meningkatkan Penguasaan Kosakata Bahasa Arab Siswa Kelas VIII MTs Nurul Huda Ketambul, Tuban. Skripsi UMM: tidak dipublikasikan.

Suprijono, Agus. 2010. Cooperative Learning. Yogyakarta. Pustaka Media. 